\title{
SIV infection of rhesus macaques of Chinese origin: a suitable model for HIV infection in humans
}

\author{
Yu Zhou ${ }^{1,3+}$, Rong Bao ${ }^{1 \dagger}$, Nancy L Haigwood ${ }^{2}$, Yuri Persidsky ${ }^{3}$ and Wen-zhe Ho ${ }^{1,3^{*}}$
}

\begin{abstract}
Simian immunodeficiency virus (SIV) infection of Indian-origin rhesus macaques (RM) has been widely used as a well-established nonhuman primate (NHP) model for HIV/AIDS research. However, there have been a growing number of studies using Chinese RM to evaluate immunopathogenesis of SIV infection. In this paper, we have for the first time reviewed and discussed the major publications related to SIV or SHIV infection of Chinese RM in the past decades. We have compared the differences in the pathogenesis of SIV infection between Chinese RM and Indian RM with regard to viral infection, immunological response, and host genetic background. Given AIDS is a disease that affects humans of diverse origins, it is of importance to study animals with different geographical background. Therefore, to examine and compare results obtained from RM models of Indian and Chinese origins should lead to further validation and improvement of these animal models for HIV/AIDS research.
\end{abstract}

Keywords: Simian immunodeficiency virus (SIV), Nonhuman primate (NHP), Chinese rhesus macaques (RM), Indian RM, HIV/AIDS

\section{Review}

\section{Introduction}

Nonhuman primate (NHP) models have been widely used to study the pathogenesis, vaccine and therapeutic intervention of HIV/AIDS since the isolation of HIV and simian immunodeficiency virus (SIV) strains [1-3]. The first use of SIV infection of rhesus macaques (RM) for testing a candidate HIV vaccine was reported in 1989 [4], after which there has been a dramatic increase in the utilization of rhesus and other macaque models in the HIV field. Multiple factors contribute to the high demand for macaques. First, there are still a multitude of preclinical HIV drugs and vaccine approaches and modalities being tested, which requires a large number of animals [5]. Second, it has been recognized that repeated mucosal exposure to low dose of SIV in rhesus macaques resembles HIV infection in humans [6]. Once the set-point phase is reached following mucosal SIV challenge, the level of viral load

\footnotetext{
* Correspondence: wenzheho@temple.edu

${ }^{\dagger}$ Equal contributors

'The Center for Animal Experiment/ ABSL-III Laboratory, State Key Laboratory of Virology, Wuhan University School of Medicine, Wuhan, Hubei 430071, P.R. China

${ }^{3}$ Department of Pathology and Laboratory Medicine, Temple University School of Medicine, Philadelphia, PA 19140, USA

Full list of author information is available at the end of the article
}

predicts the rate of progression to AIDS [7-10]. As a result, attempts to detect subtle differences in virological and immunological outcomes in vaccinated animals challenged by low dose mucosal routes of infection have greatly increased the number of animals required for each vaccine study [11]. Third, NHP models, particularly $\mathrm{RM}$, have been widely used to investigate the events of SIV infection with respect to viral dynamics, immune responses, and changes in the pool of $\mathrm{CD} 4^{+}$cells, which further enhances the need for suitable macaque hosts for studies of HIV pathogenesis [12].

There are three available macaque species [rhesus (Macaca mulatta), cynomolgus (Macaca fascicularis), and pigtail (Macaca nemestrina)] that are susceptible to SIV infection and develop AIDS-like disease [1]. Rhesus macaques of Indian origin have often been used for SIV infection as they are the primary species provided by the breeding facilities in the USA [1]. SIV infection in Indian-origin RM has become the most established model of HIV infection and AIDS-related research due to development of tools to study immune responses in depth [13] and the concomitant wealth of experimental data available. Additional research has utilized the chimeric virus, SHIV, for experiments that require HIV proteins, such as HIV envelope-based SHIVs for testing of human 
neutralizing antibodies on Indian RM, summarized in a recent review [14]. As a mainstay of nonhuman primate models in HIV/SIV research, the availability of Indian RM model has contributed greatly to our understanding of HIV transmission, pathogenesis, prevention and therapy. However, like any existing animal models for studying human diseases, the Indian RM model has its limitations. The biological discrepancies between human and simian AIDS reveal certain drawbacks of Indian RM in HIV research. For example, the progress to disease is more aggressive in Indian RM when infected with most if not all SIV strains, and the plasma viral loads are higher than HIV infection of humans [15-17]. Also, with regard to the dynamics of the $\mathrm{CD} 4^{+} \mathrm{CCR} 5^{+}$memory $\mathrm{T}$ cells, an important marker for HIV/SIV disease progression [12,18], there are some differences between SIV infection in Indian macaques and HIV infection in humans.

Belonging to the same species as Indian RM, Chinese RM have also been used in HIV/SIV research. Over the past decades, an increasing body of evidence shows that similar to RM of Indian origin, Chinese RM can be readily infected by SIV through different inoculation routes, and were proved to be useful in evaluating pathogenesis, vaccine, and therapeutic strategies for HIV/AIDS studies [15-18]. However, because of different course of SIV infection in Chinese RM compared with that in Indian RM, the use of Chinese RM in AIDS research has been limited. In this review, we describe and discuss the major publications related to SIV infection of Chinese RM over the past decades and compare the differences in SIV and SHIV infection between Chinese RM and its Indianorigin counterpart.

\section{Experimental evidence for SIV/SHIV infection of Chinese RM}

Early experimental evidence for successful infection of Chinese RM by SIV came from a study by Joag et al. [19], in which all six Chinese RM enrolled in the study developed acute plasma viremia after SIVmac239 inoculation [19]. Subsequent research demonstrated that the course of SIV infection in Chinese RM is somewhat different from that seen in Indian RM. Ling et al. utilized SIVmac239 to intravenously infect ten Chinese RM and found that all Chinese RM quickly developed viremia with magnitudes and kinetics of viral load similar to HIV infection of humans [20]. Infection of Chinese RM by SIVmac239 was further demonstrated by several other groups (Table 1). In addition to SIVmac239, infection of Chinese RM by SIVmac251, SHIV and primary virulent isolate SIV/ DeltaB670 [21], has been documented (Tables 1 and 2). Marthas and colleagues [22] found that there was no significant difference between Indian RM and Chinese RM with regard to the number of animals that were infected with intravaginal inoculation of SIV251. They observed that, although there was considerable overlap in the range of viral loads between both Indian and Chinese RM, the variation in viral loads among Indian RM was greater than that among Chinese RM [22]. In addition, SIV-infected Chinese RM tended to have the lower end of the range of viral loads compared with infected Indian RM [22]. Chen et al. compared infection of Chinese RM with two different SIV strains, SIVmac251 and SIVmac239, and observed that SIVmac239 infection was more pathogenic, as it caused more aggressive disease than SIVmac251 [9], suggesting the potential variability of bio-clinical parameters in Chinese RM when infected by different strains of SIV. Wang et al. [23] showed that a CCR5-tropic chimeric SHIV ( $\mathrm{SHIV}_{\mathrm{B}^{\prime} \mathrm{WHU}}$ ) could replicate in Chinese RM peripheral blood and cause acute infection of these animals with no significant changes in viral tropism and sequences after infection. Miyake et al. [24] infected Chinese RM with pathogenic SHIV (SHIV-C2/1-KS661c) by intrarectal inoculation and observed rapid dissemination of SIV to multiple organs, including rectum, thymus and axillary lymph node (LN) as early as three days post infection. Further analysis of viral kinetics showed that infectious virus was first detected at day six post infection (p.i.) and high levels of proviral DNA and infectious virus were both detected by 13 days p.i.. However, by 27 days p.i., SIV loads decreased dramatically. Pal et al. [25] demonstrated that replication competent SHIV encoded HIV reverse transcriptase gene (RT SHIV) could be transmitted efficiently via the vaginal route in Chinese RM. Some of these infected animals had persisting viremia for one year. In a co-infection model, Chenine et al. showed that Chinese RM were able to be infected by clade C SHIV (SHIV-C) and the infection was significantly facilitated by the parasite co-infection [26].

In addition to the successful establishment of SIV infection in Chinese RM as described above, investigators have also utilized SIV infection of Chinese RM to recapitulate the host immune activation of HIV infection, including immune cell proliferation, activation, and apoptosis. Several studies have found occurrences of marked immune activation and lymphocyte apoptosis in Chinese RM following SIV infection, which are the key pathogenic factors during SIV infection of RM [10,40,55,56]. A study by Monceaux et al. documented that extensive apoptosis in lymphoid organs indicates rapid AIDS progression during primary SIVmac251 infection in Chinese RM [10]. Cumont et al. [40] also showed that there was an increase in lymphocyte apoptosis in LNs during primary SIVmac251 infection of Chinese RM, the levels of which were associated with the degree of viral replication and the rate of AIDS progression. They further demonstrated that the level of lymphocyte apoptosis in RM of Chinese origin was lower than in those of Indian RM. This study was supported by Viollet et al. [55] who reported that death of $\mathrm{CD}^{+}{ }^{+} \mathrm{T}$ cells from lymph nodes 
Table 1 Clinical parameters in SIV-infected Chinese RM

\begin{tabular}{|c|c|c|c|c|c|c|c|c|}
\hline Animal no. & Age (Year) & Gender & Inoculation $^{* *}$ & SIV strains & Dose $A^{\prime} D_{50} / T_{C I D}^{* * *}$ & Peak viral load & Survival time ${ }^{* * * *}$ & Refs \\
\hline 10 & $3-10$ & $7 F / 3 M$ & I.V. & $\operatorname{mac} 239$ & $10^{2} \mathrm{TCID}_{50}$ & $3.5 \times 10^{6}-6.0 \times 10^{7}$ & $>34 \mathrm{~W}$ & {$[20]$} \\
\hline 50 & \multirow[t]{2}{*}{$3-6$} & \multirow[t]{2}{*}{$78 \mathrm{M} / 72 \mathrm{~F}$} & I.R. & $\operatorname{mac} 239$ & $5 \times 10^{5} \mathrm{TCID}_{50}$ & $10^{7}$ & $>99 \mathrm{~W}(25 / 50)$ & \multirow[t]{2}{*}{ [9] } \\
\hline 50 & & & I.V. & $\operatorname{mac} 239$ & $2 \times 10^{2} \mathrm{TCID}_{50}$ & $10^{7}$ & $>117 W(25 / 50)$ & \\
\hline 8 & $5-11$ & M & I.V. & $\operatorname{mac} 239$ & $5 \times 10^{3} \mathrm{TCID}_{50}$ & $10^{6}-10^{8}$ & $>69 \mathrm{~W}(4 / 8)$ & {$[27]$} \\
\hline 4 & Adult & M & I.V. & $\operatorname{mac} 239$ & $5 \times 10^{3} \mathrm{TCID}_{50}$ & $5 \times 10^{6}-1 \times 10^{8}$ & $\mathrm{NP}$ & {$[28]$} \\
\hline 3 & $3-6$ & $2 \mathrm{M} / 1 \mathrm{~F}$ & I.V. & $\operatorname{mac} 239$ & $10^{3} \mathrm{TCID}_{50}$ & $3.2 \times 10^{6}-3.2 \times 10^{7}$ & $>25 \mathrm{~W}$ & [29] \\
\hline 3 & $3-8$ & Mixed & I.R. & $\operatorname{mac} 239$ & $2.5 \times 10^{3} \mathrm{TCID}_{50}$ & $10^{6}-10^{7}$ & $>44 \mathrm{~W}$ & {$[30]$} \\
\hline 9 & \multirow[t]{2}{*}{ NP } & \multirow[t]{2}{*}{ NP } & \multirow[t]{2}{*}{ I.V. } & $\operatorname{mac} 239$ & $10^{2} \mathrm{TCID}_{50}$ & \multirow[t]{2}{*}{$\sim 10^{6}-10^{8}$} & 104-354W & \multirow[t]{2}{*}{ [31] } \\
\hline 7 & & & & $\operatorname{mac} 239$ & $2 \times 10^{6}$ copies & & $31-172 W$ & \\
\hline 1 & Adult & $\mathrm{F}$ & IVAG $\times 3$ & $\operatorname{mac} 239$ & $\sim 10^{5} \mathrm{TCID}_{50}$ & $\sim 7.9 \times 10^{6}$ & $>46 \mathrm{~W}$ & [32] \\
\hline 4 & \multirow[t]{2}{*}{$N P$} & \multirow[t]{2}{*}{ NP } & \multirow[t]{2}{*}{ I.V. } & $\operatorname{mac} 251$ & $5 \times 10^{2} \mathrm{TCID}_{50}$ & \multirow[t]{2}{*}{$10^{6}-2 \times 10^{8}$} & $>18 \mathrm{M}$ & \multirow[t]{2}{*}{ [33] } \\
\hline 8 & & & & $\operatorname{mac} 239$ & NP & & $>36 \mathrm{M}$ & \\
\hline 24 & 5 & M & I.R. & $\operatorname{mac} 239$ & $10^{3} \mathrm{TCID}_{50}$ & $10^{5}-5 \times 10^{7}$ & $>24 \mathrm{~W}$ & [34] \\
\hline 2 & $5-6$ & $\mathrm{~F}$ & IVAG & $\operatorname{mac} 239$ & $10^{5} \mathrm{TCID}_{50}$ & $2.5 \times 10^{6}-3.2 \times 10^{6}$ & $>25 \mathrm{~W}$ & [35] \\
\hline 50 & $3-6$ & $\mathrm{NP}$ & I.V. & $\operatorname{mac} 251$ & $2 \times 10^{2} \mathrm{TCID}_{50}$ & $5 \times 10^{6}$ & $>118 \mathrm{~W}(27 / 50)$ & [9] \\
\hline 14 & $4-5$ & $\mathrm{~F}$ & I.V. & $\operatorname{mac} 251$ & $10^{5} \mathrm{TCID}_{50}$ & $1.1 \times 10^{5}-1.2 \times 10^{8}$ & NP & [22] \\
\hline 10 & $4-6$ & $\mathrm{~F}$ & I.V. & $\operatorname{mac} 251$ & $50 \mathrm{TCID}_{50}$ & $2.4 \times 10^{4}-1.4 \times 10^{6}$ & $51-72 W$ & {$[36]$} \\
\hline 6 & NP & NP & I.V. & $\operatorname{mac} 251$ & $10 \mathrm{AID}_{50}$ & $7.0 \times 10^{5}-3.2 \times 10^{7}$ & NP & {$[37]$} \\
\hline 10 & $7.5-9.5$ & NP & I.V. & $\operatorname{mac} 251$ & $10 \mathrm{AID}_{50}$ & $2.6 \times 10^{5}-3.6 \times 10^{7}$ & NP & [12] \\
\hline 12 & NP & $\mathrm{NP}$ & I.V. & $\operatorname{mac} 251$ & $10 \mathrm{AID}_{50}$ & $10^{5}-10^{8}$ & 5-108W (killed) & [38] \\
\hline 4 & $2-4$ & mixed & I.V. & $\operatorname{mac} 251$ & $5 \mathrm{AlD}_{100}$ & $2.7 \times 10^{7}-7.6 \times 10^{7}$ & $>42 \mathrm{~W}$ & [39] \\
\hline 8 & $\mathrm{NP}$ & NP & I.V & $\operatorname{mac} 251$ & $10 \mathrm{AID}_{50}$ & $6.7 \times 10^{5}-3.2 \times 10^{7}$ & $>154 \mathrm{~W}(4 / 8)$ & {$[40]$} \\
\hline
\end{tabular}

"NP: The information is not provided in the paper;

${ }^{*}{ }^{*}$ I.R.: intrarectally; I.V.: intravenously; IVAG: intravaginally;

${ }^{* * *} \mathrm{TCID}_{50}: 50 \%$ tissue culture infective dose; $\mathrm{AID}_{50}: 50 \%$ animal infectious doses; Viral titer was quantified in different cells;

***** W: Weeks; M: Months.

during primary SIVmac251 infection indicates the rate of disease progression to AIDS in Chinese RM. In study of the $\mathrm{CD}^{+}$and $\mathrm{CD}^{+} \mathrm{T}$ cell dynamics during the asymptomatic phase of SIVmac251 infection of Chinese RM, Monceaux et al. revealed that during the asymptomatic phase, the $\mathrm{CD} 4^{+} \mathrm{T}$ cells were sustained in the axillary LNs, while progressively depleted in the peripheral blood [57]. They also found that during primary SIV infection, the intense $\mathrm{CD} 8^{+} \mathrm{T}$ cell activation and an elevation of optimal effector $\mathrm{CD} 8^{+} \mathrm{T}$ cell function correlate with a poor prognosis for AIDS progression [56]. Similarly, Ho et al. utilized the nef-deleted SIVmac251 to infect the Chinese RM and demonstrated that the attenuated SIVmac251 induced pathological CD4 ${ }^{+} \mathrm{T}$ cell depletion in at least half of the animals, which was associated with a thymic defect [58]. Our recent studies also revealed that LPS administration induced $\mathrm{CD}^{+}{ }^{+} \mathrm{T}$ cell activation during SIVmac239 infection of Chinese RM (unpublished data). Apart from lymphocytes, other immune cells such as neutrophils, monocytes and dendritic cells, are also prone to apoptosis in pathogenic SIV infection of Chinese RM $[59,60]$. Polymorphonuclear neutrophils (PMN) in chronically HIV-infected patients were revealed to be more prone to die [60]. Similarly, neutrophils were also depleted during primary SIV infection in Chinese RM, leading to an early and sustained neutropenia in these animals [37]. Therefore, it was proposed that increased PMN death can be used as a marker to predict destruction of host defense against HIV/SIV infection $[37,59]$.

Collectively, there have been more than 70 peer-reviewed publications to date that clearly demonstrate that Chinese RM are susceptible to infection by various non-adapted SIV strains (mac182, mac251, mac239, delta B670, nefdeleted mac251) as well as by engineered SHIV (89.6, 89.6P, SF162P3, SF162P4, RT). Major clinical parameters for SIV or SHIV infection of Chinese RM in these publications are summarized in Tables 1 and 2, respectively.

\section{Differences in SIV infection between Chinese RM and Indian RM \\ Overview}

Although Chinese RM and Indian RM belong to the same species, they demonstrate differences in physiological and immunologic responses [61-63], as well as genetic background [63-66]. Therefore, it is not surprising to observe differences in infection-induced clinical and immunologic parameters and disease progression rates between Chinese 
Table 2 Clinical parameters in SHIV-infected Chinese RM

\begin{tabular}{|c|c|c|c|c|c|c|c|c|}
\hline Animal no. & Age $(\text { Year })^{*}$ & Gender & Inoculation $^{* *}$ & $\begin{array}{c}\text { SHIV } \\
\text { strains }\end{array}$ & Dose $A D_{50} / T_{C I D}^{* * * *}$ & Peak viral load in plasma & Survival time (weeks) ${ }^{* * * *}$ & Ref \\
\hline 2 & $3.5-4.5$ & mixed & I.R. & $89.6 \mathrm{P}$ & $40 \mathrm{AID}_{50}$ & $8 \times 10^{5}-7 \times 10^{6}$ & $>24 \mathrm{~W}$ & [41] \\
\hline 10 & $6.1-7.1$ & NP & I.V. & $89.6 \mathrm{P}$ & $10^{3} \mathrm{AID}_{50}$ & $1 \times 10^{7}$ & $>36 \mathrm{~W}$ & [42] \\
\hline 6 & $4-5$ & NP & I.V. & $89.6 \mathrm{P}$ & $20 \mathrm{AID}_{50}$ & $\sim 2 \times 10^{5}-3 \times 10^{6}$ & $>40 \mathrm{~W}(5 / 6)$ & [43] \\
\hline 6 & $4-8$ & NP & I.V. & $89.6 P$ & $10^{3} \mathrm{AlD}_{50}$ & NP & NP & {$[44]$} \\
\hline 6 & $\mathrm{NP}$ & $\mathrm{F}$ & IVAG (13 times) & SF162P3 & $20,30 \mathrm{TCID}_{50}$ & $6.3 \times 10^{5}-1.6 \times 10^{7}$ & $>29 \mathrm{~W}$ & {$[45]$} \\
\hline 8 & $3-5$ & $\mathrm{~F}$ & I.V. & SF162P4 & $18 \mathrm{AID}_{50}$ & $1.6 \times 10^{5}-2.5 \times 10^{6}$ & $>10 \mathrm{~W}$ & {$[46]$} \\
\hline 8 & $5-6$ & $\mathrm{~F}$ & I.V. & SF162P4 & $22 \mathrm{TCID}_{50}$ & $1.6 \times 10^{5}-3.2 \times 10^{6}$ & $>10 \mathrm{~W}$ & [47] \\
\hline 12 & $3.5-7$ & $\mathrm{~F}$ & IVAG (6 times) & SF162P3 & $3 \times 10^{2} \mathrm{TCID}_{50}$ & $1.1 \times 10^{6}-3.5 \times 10^{6}$ & $\mathrm{~N} / \mathrm{P}$ & [48] \\
\hline 4 & Adult & M & I.R. & SF162P3 & $10 \mathrm{TCID}_{50}$ & $\sim 10^{6}-10^{7}$ & $>32 \mathrm{~W}$ & [49] \\
\hline 10 & $5-15$ & $\mathrm{~F}$ & IVAG & SF162P3 & $3 \times 10^{2} \mathrm{TCID}_{50}$ & $3.2 \times 10^{5}-1 \times 10^{8}$ & $\geq 10 \mathrm{~W}$ & [50] \\
\hline 8 & $\mathrm{NP}$ & $7 \mathrm{M} / 1 \mathrm{~F}$ & I.R. (M) IVAG (F) & SF162p3 & $10 \mathrm{TCID}_{50}$ & NP & $\mathrm{NP}$ & [51] \\
\hline 4 & \multirow[t]{2}{*}{8.09 (mean) } & \multirow[t]{2}{*}{$N P$} & \multirow[t]{2}{*}{ I.R. } & \multirow[t]{2}{*}{ RT } & $10^{3} \mathrm{TCID}_{50}$ & $1 \times 10^{4}-2 \times 10^{6}$ & $>20 \mathrm{~W}$ & \multirow[t]{2}{*}{ [52] } \\
\hline 2 & & & & & $10^{4} \mathrm{TCID}_{50}$ & $5 \times 10^{5}-2 \times 10^{7}$ & $>16 \mathrm{~W}$ & \\
\hline 5 & \multirow[t]{2}{*}{ Adult } & \multirow[t]{2}{*}{$\mathrm{F}$} & \multirow[t]{2}{*}{ IVAG } & \multirow[t]{2}{*}{ RT } & $10^{3} \mathrm{TCID}_{50}$ & $2 \times 10^{6}-2 \times 10^{7}$ & $>20 \mathrm{~W}$ & \multirow[t]{2}{*}{53} \\
\hline 2 & & & & & $2 \times 10^{2} \mathrm{TCID}_{50}$ & $1 \times 10^{6}(1 / 2)$ & $>20 \mathrm{~W}$ & \\
\hline 16 & \multirow[t]{2}{*}{$4-12$} & \multirow[t]{2}{*}{$\mathrm{F}$} & \multirow[t]{2}{*}{ IVAG } & \multirow[t]{2}{*}{ RT } & \multirow[t]{2}{*}{$10^{3} \mathrm{TCID}_{50}$} & $10^{5}-10^{7}(9 / 16)$ & \multirow[t]{2}{*}{$>16 \mathrm{~W}$} & \multirow[t]{2}{*}{54} \\
\hline 30 & & & & & & $\sim 4 \times 10^{4}-6 \times 10^{7}(22 / 30)$ & & \\
\hline
\end{tabular}

"NP: The information is not provided in the paper;

${ }_{* * *}^{*}$ I.R.: intrarectally; I.V.: intravenously; IVAG: intravaginally;

${ }^{* * *} \mathrm{TCID}_{50}: 50 \%$ tissue culture infective dose; $\mathrm{AID}_{50}: 50 \%$ animal infectious doses; Viral titer was quantified in different cells;

**** W: Weeks; M: Months.

RM and Indian RM following SIV infection. Table 3 summarizes the published observations on the differences in SIV infection between Chinese RM and Indian RM.

\section{Differences in virological impact}

Ling et al. demonstrated that although there was little difference in peak viral load between Chinese RM and Indian RM, the former had a significantly lower set point viral load than the latter ( 2.8-6.7 vs. $6-7$ at $\lg 10$ scale) [20]. Such a difference in viral load between Chinese and Indian-origin RM was also observed for SIVmac251 infection at various inoculation doses [8,22,40]. Using SIVmac182, the steady-state plasma viral loads achieved in Indian monkeys were significantly higher than those found in Chinese macaques [67]. A difference in survival between the two origins of RM after SIV infection was also observed. For example, four out of eight Chinese RM survived for longer than 154 weeks after viral infection, whereas in the same study all Indian RM died 54 weeks after infection [40]. There has been strong support in the HIV vaccine field for using Indian RM infected with SIVmac239 due to the high, persistent and reproducible plasma viremia. This property of Indian RM made them the model of preference for vaccines that blunt viremia but do not prevent infection, such as the rhesus cytomegalovirus (CMV) vaccines [68,69]. In these types of challenge studies, very large numbers of $\mathrm{RM}$ are needed to determine differences between groups since all animals become infected. A concern over SHIV models has arisen due to their lack of predictability for human trials [70]. However, in examining of HIV vaccines, or testing of passively transferred neutralizing antibodies that can block HIV/SIV infection or enhance immunity [71], the relatively low SHIV load in set point viremia observed in individual Chinese RM is not a disadvantage because significantly different outcomes can be measured with smaller numbers of macaques [72,73].

\section{Differences in immunologic response}

Chinese RM infected with SIVmac239 demonstrated strong antibody responses; ten out of ten infected Chinese RM had positive antibody responses [20]. In contrast, only one out of four infected Indian RM showed the production of antibodies [20]. A similar pattern was observed for CD4 perseverance, as seven out of ten Chinese $\mathrm{RM}$ had $>50 \%$ CD4/CD8 ratio, while two out of four Indian $\mathrm{RM}$ had $<50 \% \mathrm{CD} 4 / \mathrm{CD} 8$ ratio [20]. The study by Monceaux et al. [12] showed that the dynamics of CCR5-expressing CD4+ T cells in the acute phase of SIV-infection in Chinese RM are very similar to those in HIV-infected humans, which is characterized as a transient increase in the proportion of CD4+CCR5+ $\mathrm{T}$ cells in the peripheral blood. In contrast, in SIVinfected Indian RM, the number of CD4 + CCR5 + T cells declined in a more immediate and sustained fashion. The authors further demonstrated that such relative expansion 
Table 3 Comparison of key parameters in Chinese RM and Indian RM following SIV infection

\begin{tabular}{|c|c|c|c|c|c|c|c|c|}
\hline $\begin{array}{l}\text { Innoculation } \\
\text { route }\end{array}$ & $\begin{array}{l}\text { SIV strains } \\
\text { (Titer) }\end{array}$ & Rhesus macaque & $\begin{array}{l}\text { Peak viral } \\
\text { load (Ig10) }\end{array}$ & $\begin{array}{l}\text { Set point } \\
\text { viral load } \\
(\lg 10)^{*}\end{array}$ & $\begin{array}{c}\text { CD4 + T cells } \\
(\%)\end{array}$ & Antibody titer** & Survival time ${ }^{* * *}$ & Ref \\
\hline \multirow[t]{6}{*}{ I.V. } & mac239 & Chinese RM $(n=10)$ & $6.5-7.8$ & $\sim 2.8-6.7$ & $>50 \%$ (7 out of 10) & 10 out of 10 positive & NP & [20] \\
\hline & $\left(10^{2} \mathrm{TCID}_{50}\right)$ & Indian RM $(n=4)$ & $7-8$ & $\sim 6-7$ & $<50 \%$ (2 out of 4$)$ & 1 out of 4 & $>17 \mathrm{~W}(2 / 4)$ & \\
\hline & $\operatorname{mac} 251$ & Chinese RM $(n=8)$ & $5.8-7.5$ & $2.5-5.8$ & NP & NP & $>154 \mathrm{~W}(4 / 8)$ & [40] \\
\hline & $\left(10 \mathrm{TCID}_{50}\right)$ & Indian RM ( $n=6)$ & $6.9-7.8$ & $4.5-7.3$ & $\mathrm{NP}$ & $\mathrm{NP}$ & $<52 \mathrm{~W}$ & \\
\hline & mac251 & Chinese RM $(n=8)$ & $6.47-7.88$ & $3.62-5.70$ & $51 \%$ & $\sim 10^{3}$ & $>43 W(8 / 8)$ & [8] \\
\hline & $\left(10^{2} \mathrm{TCID}_{50}\right)$ & Indian RM $(n=15)$ & $6.64-8.30$ & $4.37-7.30$ & $49 \%$ & $\sim 10^{3}$ & $>43 W(10 / 15)$ & \\
\hline \multirow[t]{2}{*}{ IVAG } & $\operatorname{mac} 251$ & Chinese RM $(n=10)$ & 7.2 & 5.0 & NP & $1.6 \times 10^{4}-8 \times 10^{5}$ & NP & [22] \\
\hline & $\left(10^{5} \mathrm{TCID} \mathrm{D}_{50}\right)$ & Indian RM $(n=16)$ & 7.7 & 6.3 & $\mathrm{NP}$ & $2 \times 10^{2}-8 \times 10^{5}$ & NP & \\
\hline
\end{tabular}

: : Measured at day 35-77;

:* : Measured at wk15-16;

*****: Weeks.

of the CD4+ CCR5+ $\mathrm{T}$ cells in SIVmac251-infected Chinese RM was associated with most markers of active disease progression, including high virus replication, overall loss of $\mathrm{CD} 4+\mathrm{T}$ cell function, time to development of AIDS, and overall survival rate [12]. In addition, Cumont et al. [40] found that Indian RM demonstrated a profound decline in the percentage of $\mathrm{CD}^{+} \mathrm{DR}^{+} \mathrm{T}$ cells during SIVmac251 infection, while only a transient decrease of $\mathrm{CD}^{+} \mathrm{DR}^{+} \mathrm{T}$ cells was observed in Chinese RM at the peak of virus replication. Moreover, they found that in SIVmac251-infected RM, the frequency of TiA-1-expressing T cells expanded earlier in Indian RM than those in Chinese RM. However, at day 60 p.i., the level of TiA-1 reactivity in Chinese RM became greater than that in Indian RM infected with SIVmac251 [40].

The gastrointestinal (GI) tract is a major site of HIV replication. It has been shown that both acute HIV and SIV infections could result in a dramatic and selective loss of memory $\mathrm{CD} 4^{+} \mathrm{T}$ cells predominantly from the mucosal surfaces in GI tract [74,75]. The drastic but transient depletion of $\mathrm{CD}^{+}{ }^{+} \mathrm{T}$ cells in the intestine was also found in SIV infection of Chinese RM [76]. Th17 cells are a subset of recently identified $\mathrm{CD} 4^{+} \mathrm{T}$ helper cells that are critical for mucosal immunity. A loss of Th17 cells in the GI tracts has been shown to be associated with disease progression in pathogenic HIV-infected humans, and SIV-infected RM [77-79]. However, in Chinese RM such low frequency of Th17 CD4 cells could be compensated by the emergence of NK T cells that express IL-17 early after infection [76]. In addition to the $\mathrm{T}$ cell decline, neutrophils were also found to be depleted early in pathogenic SIV infection in both Indian and Chinese RM [37]. This SIV-infection mediated neutropenia coincided with the peak of viral replication. To compare with Chinese RM, the neutropenia was more severe and more sustained in Indian RM, which is consistent with the overall higher pathogenicity of SIV infection in Indian RM than that in Chinese RM [37].
With respect to the innate antiviral cytokine response to SIV infection, it was found that both pathogenic SIVmac251 and non-pathogenic nef-deleted SIVmac251 infection induced more remarkable type I IFN expression in the lymphoid tissues of Indian RM than Chinese RM [80]. The authors also showed that pathogenic SIVmac251 infection induced a stronger type I IFN response in lymphoid tissues than nef-deleted SIVmac251, with more aggressive disease progression. They speculated that the increased type I IFN response in pathogenic SIV infection might be due to the increased recruitment of plasmacytoid dendritic cells (pDC) in the peripheral LNs and elevated inflammatory environment. On the other hand, decreased type I IFN expression correlates with reduced pDC recruitment in non-pathogenic SIV infection [80]. In SIV infection of natural hosts, such as African green monkeys (AGMs), the absence of sustained IFN production is related to the absence of viral persistence in LNs at the chronic phase [80].

\section{The mechanisms for the differences between SIV infected} Indian RM and Chinese RM models

The mechanisms for the differences in SIV-induced disease pathogenesis between Chinese RM and Indian RM remain largely unclear. It is likely that multiple factors including viral fitness, immunological responses, and genetic background could all contribute to the divergence between Indian RM and Chinese RM as an NHP model for HIV/AIDS research.

\section{Viral fitness}

The natural adaption of the SIV strains from Indian to Chinese RM is believed to be critical in determining viral infectivity. It has been shown that compared to Indian RM, SIVmac strains are less well adapted in Chinese RM with limited replication capacity $[8,20,22]$, leading to slower depletion of memory CCR $5^{+} \mathrm{CD} 4^{+} \mathrm{T}$ cells in the intestinal mucosa in Chinese RM compared 
to Indian RM [81]. This assumption is further supported by the observation that in vivo serial passage of SIV in Chinese RM led to enhanced viral infectivity [67]. In addition, increased viral fitness from Indian RM cells may explain the higher replicative ability and faster rate of disease progression in these animals, as some of the earlier studies were performed using virus preparations acquired from repeated serial passage in cells from Indian RM. However, Cumont et al. used an SIVmac251 strain that had been in vitro passaged in peripheral blood mononuclear cells derived from Chinese RM, but still observed an accelerated course of disease in Indian RM, with higher apoptosis in Indian RM than in Chinese RM. This finding suggests that rather than intrinsic properties of SIV, host factors are pivotal determinants of the divergent outcomes of SIV infection in rhesus macaques [40].

\section{Host immunological factors}

Quantification of the copy numbers of CCL3L, a CCR5 ligand that blocks viral entry, identified that Indian RM usually harbor much lower copy number of CCL3L compared to Chinese RM, suggesting that slower progression of SIV infection in Chinese RM may be a result of a block in entry by increased CCL3L in these animals [82]. In terms of adaptive immune response, it was shown that Chinese RM demonstrated stronger and longer lasting antiviral antibody response as well as SIV-specific CD8 CTL response [81] than Indian RM after SIV infection [20]. To explain the differences between Indian and Chinese RM with respect to how SIV infection affects the dynamics of CD4+CCR5+ T cells, Monceaux et al. proposed that since the drastic decline of the pool of CD4 + CCR5+ T cells in Indian RM is a key factor for the rapid disease progression during both acute and chronic infection, the direct effect of virus replication [12] might be the major determinant of the immune dysfunction that implicates the disease progression to AIDS and death. In contrast, SIV-infected Chinese RM undergo a relative expansion of the CD $4+\mathrm{CCR} 5+\mathrm{T}$ cell pool, the degree of which is correlated with all markers of disease progression. Thus, the effect of immune activation, instead of infection-mediated cell lysis [12], may be a pivotal determinant in the immunological changes related to AIDS progression in Chinese RM.

\section{Genetic divergence}

In addition to viral and host immunological factors, host genetic factors should also be taken into consideration in understanding of biological differences in SIV infection between the Indian and Chinese RM. Despite belonging to the same species, Chinese RM and Indian RM have diverged into two separate subtypes with marked genetic difference, which could greatly impact viral fitness and host immune responses to the viruses that in turn markedly regulate disease progression in monkeys [9]. The genomic sequencing of Chinese RM and Indian RM has identified numerous distinguished subtype-specific single nucleotide polymorphisms (SNPs) between these monkeys [83]. Further comparisons of Indian RM and Chinese RM mitochondrial DNA (mtDNA) sequences have shown 90\% mtDNA genetic heterogeneity [84]. Furthermore, considerable differences in MHC class I and II profiles between Indian RM and Chinese RM greatly shape their adaptive immune responses to viruses and subsequently affect disease pathogenesis. Specific MHC profiles of Chinese RM have been identified to be associated with SIV inhibition [85-88]. The potential differences in MHC profile [63-66] may invoke differences in cellular restriction factors and $\mathrm{T}$ cell immune responses. Wambua et al. sequenced a cohort of 12 SIVinfected Chinese RM for the expression of MHC class I alleles and identified that one set of alleles, Mamu-B*1001, and $-B * 8701$, appeared only in some elite controllers and not in normal progressors, whereas several alleles, like Mamu-B*3901, only appeared in animals that progressed to AIDS but not in elite controllers [89]. A recent study [90] suggests that Chinese RM are valuable as representative models of HLA gene diversity and function, and therefore an attractive alternative model for investigating human immune response. However, future studies on direct comparison of MHC profiles between Chinese $\mathrm{RM}$ and Indian RM are necessary in order to identify the MHC alleles that are associated with lentivirusinduced disease outcome in these two subspecies of RM.

\section{Chinese RM as a model for testing new HIV vaccine approaches and therapy}

Several studies $[41,43,49]$ have utilized Chinese RM to evaluate novel HIV vaccine approaches and therapies. Stolte-Leeb et al. investigated the protective efficacy of the multigenic DNA prime/MVA boost vaccine approach against mucosal SHIV89.6P infection in Chinese RM by either systemic or combined systemic/mucosal application of vaccines, showing that both immunization strategies induced immune control of virus replication and protected Chinese RM from disease progression with combined systemic/mucosal vaccination [41]. In another pre-clinical study [43], immune-response profiles and protective efficacy of different HIV vaccine modalities, including DNA, protein or both, were evaluated in SHIV89.6Pchallenged Chinese RM. All vaccine modalities elicited significant immune responses. Importantly, these responses efficiently suppressed the viral replication that was otherwise sustained at high levels in non-vaccinated Chinese RM [43].

Chinese RM have also been examined for immunebased therapeutic approaches for HIV/AIDS. The current 
concept of AIDS immune therapy has been focused on cytokine-mediated retrieval of $\mathrm{T}$ cell expansion. Studies from different groups examined the impact of recombinant IL-2 (rIL-2) on T cell homeostasis in Chinese RM in the context of SIV infection, and found that administering rIL-2 caused a dose dependent expansion of $\mathrm{CD}^{+}$and $\mathrm{CD}^{+}{ }^{+} \mathrm{T}$ cells without affecting viral load, in which both $\mathrm{CD}^{+}$and $\mathrm{CD}^{+}$regulatory $\mathrm{T}$ cells were upregulated [91]. In addition to IL-2, IL-7, a critical cytokine participating in both thymopoiesis and peripheral $\mathrm{T}$ cell homeostasis, has also been tested for its therapeutic effect on HIV infection [92]. An interesting study [93] evaluated the effect of IL-7 as a therapeutic approach on immune reconstitution in SIV-infected Chinese RM. The results showed that IL-7 treatment elevated the number of circulating $\mathrm{CD} 4^{+}$and $\mathrm{CD} 8^{+}$memory $\mathrm{T}$ cells that express proliferation (Ki-67) and activation (HLA-DR, CD25) markers, as well as the naïve T cell pool (CD45RAbright CD62L). This study [92,93] also demonstrated that IL-7 therapy did not counteract the reduced plasma viral load achieved under antiretroviral therapy (ART). However, the prognostic effect of treatments with these cytokines on SIV disease outcome needs further investigation using RM, and could well utilize Chinese RM.

In addition to vaccine- and cytokine-based therapies, other novel therapeutic concepts have also been successfully tested in SIV-infected Chinese RM. It was shown that immune manipulation of delta-gamma $\mathrm{T}$ cells by a well-defined HMBPP [(E)-4-Hydroxy-3-methyl-but-2-enyl pyrophosphate)]/IL-2 therapeutic regimen could overcome virus-induced immune suppression and confer immunological benefits during the chronic phase of SIV infection of Chinese RM [42]. The antiretroviral drug, tenofovir disoproxil fumarate (TDF), was effective in blocking SHIV infection of Chinese RM [49]. These observations support the feasibility to utilize Chinese RM as a suitable NHP model for testing novel HIV therapeutic concepts.

\section{Conclusions}

Although the published data have demonstrated that Chinese RM is a suitable macaque host for studies of HIV disease, more extensive investigations on testing of current HIV vaccine approaches in Chinese RM are needed in order to determine if efficacy of these approaches in humans can be predicted in Chinese RM. These future studies should provide further support for the use of Chinese RM for the investigation of HIV disease.

\section{Abbreviations}

AGM: African green monkey; $\mathrm{AID}_{50}$ : 50\% animal infectious doses;

AIDS: Acquired immunodeficiency syndrome; CCL: Chemokine ligand; CCR5: C-C chemokine receptor 5; CD: Cluster of differentiation; Ch RM: Chinese rhesus macaques; CMV: Cytomegalovirus; CTL: Cytotoxic T Lymphocyte; DC: Dendritic cells; HIV: Human immunodeficiency virus; HLA: Human leukocyte antigen; HMBPP: (E)-4-Hydroxy-3-methyl-but-2-eny pyrophosphate; IFN: Interferon; IL: Interleukin; LN: Lymph node; I. R: Intrarectally; I.V: Intravenously; IVAG: Intravaginally; MHC: Major histocompatibility complex; mtDNA: Mitochondrial DNA; NHP: Nonhuman primate; PMN: Polymorphonuclear neutrophils; SHIV: Simian-human immunodeficiency virus; SIV: Simian immunodeficiency virus; SNP: Specific single nucleotide polymorphisms; TCID $_{50}$ : 50\% tissue culture infective dose; TDF: Tenofovir disoproxil fumarate.

\section{Competing interests}

The authors declare that they have no competing interests.

\section{Authors' contributions}

YZ wrote the manuscript. RB collected information for tables. NH, YP and WZH reviewed and edited the manuscript. All authors read and approved the final manuscript.

\section{Acknowledgement}

This work was supported by the National Institutes of Health grants DA027550, DA012815 and DA022177 to W.Z. Ho and OD011092 to N. Haigwood. We apologize to authors whose work could not be cited in this review due to space restrictions.

\section{Author details}

'The Center for Animal Experiment/ ABSL-III Laboratory, State Key Laboratory of Virology, Wuhan University School of Medicine, Wuhan, Hubei 430071, P.R. China. ${ }^{2}$ Oregon National Primate Research Center, Oregon Health \& Science University, Beaverton, OR 97006, USA. ${ }^{3}$ Department of Pathology and Laboratory Medicine, Temple University School of Medicine, Philadelphia, PA 19140, USA.

Received: 6 June 2013 Accepted: 6 August 2013

Published: 15 August 2013

\section{References}

1. Daniel MD, Letvin NL, King NW, Kannagi M, Sehgal PK, Hunt RD, Kanki PJ, Essex M, Desrosiers RC: Isolation of T-cell tropic HTLV-III-like retrovirus from macaques. Science 1985, 228:1201-1204.

2. Kanki PJ, McLane MF, King NW Jr, Letvin NL, Hunt RD, Sehgal P, Daniel MD, Desrosiers RC, Essex M: Serologic identification and characterization of a macaque T-lymphotropic retrovirus closely related to HTLV-III. Science 1985, 228:1199-1201.

3. Letvin NL: Animal models for AIDS. Immunol Today 1990, 11:322-326.

4. Desrosiers R, Wyand M, Kodama T, Ringler D, Arthur L, Sehgal P, Letvin N, King N, Daniel M: Vaccine protection against simian immunodeficiency virus infection. Proc Natl Acad Sci U S A 1989, 86:6353-6357.

5. Walker BD, Ahmed R, Plotkin S: Moving ahead an HIV vaccine: use both arms to beat HIV. Nat Med 2011, 17:1194-1195.

6. Reynolds MR, Weiler AM, Piaskowski SM, Kolar HL, Hessell AJ, Weiker M, Weisgrau KL, León EJ, Rogers WE, Makowsky R: Macaques vaccinated with simian immunodeficiency virus SIVmac239 $\Delta$ nef delay acquisition and control replication after repeated low-dose heterologous SIV challenge. J Virol 2010, 84:9190-9199.

7. Watson A, Ranchalis J, Travis B, McClure J, Sutton W, Johnson PR, Hu S-L, Haigwood NL: Plasma viremia in macaques infected with simian immunodeficiency virus: plasma viral load early in infection predicts survival. J Virol 1997, 71:284-290.

8. Reimann KA, Parker RA, Seaman MS, Beaudry K, Beddall M, Peterson L, Williams KC, Veazey RS, Montefiori DC, Mascola JR: Pathogenicity of simian-human immunodeficiency virus SHIV-89.6 P and SIVmac is attenuated in cynomolgus macaques and associated with early T-lymphocyte responses. J Virol 2005, 79:8878

9. Chen S, Lai C, Wu X, Lu Y, Han D, Guo W, Fu L, Andrieu JM, Lu W: Variability of Bio-Clinical Parameters in Chinese-Origin Rhesus Macaques Infected with Simian Immunodeficiency Virus: A Nonhuman Primate AIDS Model. PLoS One 2011, 6:e23177.

10. Monceaux V, Estaquier J, Février M, Cumont M-C, Rivière $Y$, Aubertin A-M, Ameisen JC, Hurtrel B: Extensive apoptosis in lymphoid organs during primary SIV infection predicts rapid progression towards AIDS. Aids 2003, $17: 1585-1596$

11. McDermott AB, Mitchen J, Piaskowski S, De Souza I, Yant LJ, Stephany J, Furlott J, Watkins DI: Repeated low-dose mucosal simian 
immunodeficiency virus SIVmac239 challenge results in the same viral and immunological kinetics as high-dose challenge: a model for the evaluation of vaccine efficacy in nonhuman primates. J Virol 2004, 78:3140-3144

12. Monceaux V, Viollet L, Petit F, Cumont M, Kaufmann G, Aubertin A, Hurtrel B, Silvestri G, Estaquier J: CD4+ CCR5+ T-cell dynamics during simian immunodeficiency virus infection of Chinese rhesus macaques. J Virol 2007, 81:13865-13875

13. Walker JM, Maecker HT, Maino VC, Picker L: Multicolor flow cytometric analysis in SIV-infected rhesus macaque. Method Cell Biol 2004, 75:535-557.

14. Lifson JD, Haigwood NL: Lessons in nonhuman primate models for AIDS vaccine research: from minefields to milestones. Cold Spring Harb Perspect Med 2012, 2:1-20.

15. Smith SM, Holland B, Russo C, Dailey PJ, Marx PA, Connor Rl: Retrospective analysis of viral load and SIV antibody responses in rhesus macaques infected with pathogenic SIV: predictive value for disease progression. AIDS Res Hum Retroviruses 1999, 15:1691-1701.

16. Lifson JD, Rossio JL, Piatak M, Parks T, Li L, Kiser R, Coalter V, Fisher B, Flynn BM, Czajak S: Role of CD8+ lymphocytes in control of simian immunodeficiency virus infection and resistance to rechallenge after transient early antiretroviral treatment. J Virol 2001, 75:10187-10199.

17. Mellors JW, Rinaldo CR Jr, Gupta P, White RM, Todd JA, Kingsley LA: Prognosis in HIV-1 infection predicted by the quantity of virus in plasma. Science 1996, 272:1167-1170.

18. Mattapallil JJ, Letvin NL, Roederer M: T-cell dynamics during acute SIV infection. Aids 2004, 18:13-23.

19. Joag SV, Stephens EB, Adams RJ, Foresman L, Narayan O: Pathogenesis of SIVmac infection in Chinese and Indian rhesus macaques: effects of splenectomy on virus burden. Virology 1994, 200:436-446.

20. Ling B, Veazey RS, Luckay A, Penedo C, Xu K, Lifson JD, Marx PA: SIV(mac) pathogenesis in rhesus macaques of Chinese and Indian origin compared with primary HIV infections in humans. Aids 2002, 16:1489-1496.

21. Trichel AM, Rajakumar PA, Murphey-Corb M: Species-specific variation in SIV disease progression between Chinese and Indian subspecies of rhesus macaque. J Med Primatol 2002, 31:171-178.

22. Marthas ML, Lu D, Penedo MC, Hendrickx AG, Miller CJ: Titration of an SIVmac251 stock by vaginal inoculation of Indian and Chinese origin rhesus macaques: transmission efficiency, viral loads, and antibody responses. AIDS Res Hum Retroviruses 2001, 17:1455-1466.

23. Wang H, Zhuang K, Liu L, Tang Z, Tang J, Tien P, Zhang L, Chen Z: Acute infection of Chinese macaques by a CCR5-tropic SHIV carrying a primary HIV-1 subtype B' envelope. JAIDS 2010, 53:285-291.

24. Miyake A, Ibuki K, Enose Y, Suzuki H, Horiuchi R, Motohara M, Saito N, Nakasone T, Honda M, Watanabe T, et al: Rapid dissemination of a pathogenic simian/human immunodeficiency virus to systemic organs and active replication in lymphoid tissues following intrarectal infection. J Gen Virol 2006, 87:1311-1320.

25. Pal R, Nuttall J, Galmin L, Weiss D, Chung HK, Romano J: Characterization of vaginal transmission of a simian human immunodeficiency virus (SHIV) encoding the reverse transcriptase gene from HIV-1 in Chinese rhesus macaques. Virology 2009, 386:102-108.

26. Chenine AL, Shai-Kobiler E, Steele LN, Ong H, Augostini P, Song R, Lee SJ, Autissier P, Ruprecht RM, Secor WE: Acute Schistosoma mansoni infection increases susceptibility to systemic SHIV clade C infection in rhesus macaques after mucosal virus exposure. PLoS Negl Trop Dis 2008, 2:e265.

27. Xia HJ, Zhang GH, Ma JP, Dai ZX, Li SY, Han JB, Zheng YT: Dendritic cell subsets dynamics and cytokine production in SIVmac239-infected Chinese rhesus macaques. Retrovirology 2010, 7:102.

28. Xia HJ, Ma JP, Zhang GH, Han JB, Wang JH, Zheng YT: Effect of Plasma Viremia on Apoptosis and Immunophenotype of Dendritic Cells Subsets in Acute SIVmac239 Infection of Chinese Rhesus Macaques. PLoS One 2011, 6:e29036.

29. Sun C, Zhang L, Zhang M, Liu Y, Zhong M, Ma X, Chen L: Induction of balance and breadth in the immune response is beneficial for the control of SIVmac239 replication in rhesus monkeys. J Infect 2010, 60:371-381

30. Boyer JD, Robinson TM, Maciag PC, Peng X, Johnson RS, Pavlakis G, Lewis MG, Shen A, Siliciano R, Brown CR, et al: DNA prime Listeria boost induces a cellular immune response to SIV antigens in the rhesus macaque model that is capable of limited suppression of SIV239 viral replication. Virology 2005, 333:88-101.
31. Ling B, Veazey RS, Hart M, Lackner AA, Kuroda M, Pahar B, Marx PA: Early restoration of mucosal CD4 memory CCR5 T cells in the gut of SIV-infected rhesus predicts long term non-progression. Aids 2007, 21:2377.

32. Busch M, Abel K, Li J, Piatak M Jr, Lifson JD, Miller CJ: Efficacy of a SHIV 89.6 proviral DNA vaccine against mucosal SIVmac239 challenge. Vaccine 2005, 23:4036-4047.

33. Ling B, Mohan M, Lackner AA, Green LC, Marx PA, Doyle LA, Veazey RS: The large intestine as a major reservoir for simian immunodeficiency virus in macaques with long-term, nonprogressing infection. J Infect Dis 2010, 202:1846-1854.

34. Vagenas P, Williams VG, Piatak M Jr, Bess JW Jr, Lifson JD, Blanchard JL, Gettie A, Robbiani M: Tonsillar application of AT-2 SIV affords partial protection against rectal challenge with SIVmac239. JAIDS 2009, 52:433-442.

35. Abel K, Compton L, Rourke T, Montefiori D, Lu D, Rothaeusler K, Fritts L, Bost K, Miller CJ: Simian-human immunodeficiency virus SHIV89. 6-induced protection against intravaginal challenge with pathogenic SIVmac239 is independent of the route of immunization and is associated with a combination of cytotoxic T-lymphocyte and alpha interferon responses. J Virol 2003, 77:3099-3118.

36. Sanders-Beer B, Babas T, Mansfield K, Golightly D, Kramer J, Bowlsbey A, Sites D, Nieves-Duran L, Lin S, Rippeon S, et al: Depo-Provera does not alter disease progression in SIVmac-infected female Chinese rhesus macaques. AIDS Res Hum Retroviruses 2010, 26:433-443.

37. Elbim C, Monceaux V, Mueller YM, Lewis MG, François S, Diop O, Akarid K, Hurtrel B, Gougerot-Pocidalo M-A, Lévy Y: Early divergence in neutrophil apoptosis between pathogenic and nonpathogenic simian immunodeficiency virus infections of nonhuman primates. J Immunol 2008, 181:8613-8623.

38. Cumont MC, Monceaux V, Viollet L, Lay S, Parker R, Hurtrel B, Estaquier J: TGF-beta in intestinal lymphoid organs contributes to the death of armed effector CD8 T cells and is associated with the absence of virus containment in rhesus macaques infected with the simian immunodeficiency virus. Cell Death Differ 2007, 14:1747-1758.

39. Lu W, Wu X, Lu Y, Guo W, Andrieu JM: Therapeutic dendritic-cell vaccine for simian AIDS. Nat Med 2002, 9:27-32.

40. Cumont M-C, Diop O, Vaslin B, Elbim C, Viollet L, Monceaux V, Lay S, Silvestri G, Le Grand R, Müller-Trutwin M: Early divergence in lymphoid tissue apoptosis between pathogenic and nonpathogenic simian immunodeficiency virus infections of nonhuman primates. J Virol 2008, 82:1175-1184.

41. Stolte-Leeb N, Bieler K, Kostler J, Heeney J, Haaft PT, Suh YS, Hunsmann G, Stahl-Hennig C, Wagner R: Better protective effects in rhesus macaques by combining systemic and mucosal application of a dual component vector vaccine after rectal SHIV89.6P challenge compared to systemic vaccination alone. Viral Immunol 2008, 21:235-246.

42. Ali Z, Yan L, Plagman N, Reichenberg A, Hintz M, Jomaa H, Villinger F, Chen ZW: Gammadelta T cell immune manipulation during chronic phase of simian-human immunodeficiency virus infection [corrected] confers immunological benefits. J Immunol 2009, 183:5407-5417.

43. Koopman G, Mortier D, Hofman S, Mathy N, Koutsoukos M, Ertl P, Overend P, van Wely C, Thomsen LL, Wahren B, et al: Immune-response profiles induced by human immunodeficiency virus type 1 vaccine DNA, protein or mixed-modality immunization: increased protection from pathogenic simian-human immunodeficiency virus viraemia with protein/DNA combination. J Gen Virol 2008, 89:540-553.

44. Ryan-Payseur B, Ali Z, Huang D, Chen CY, Yan L, Wang RC, Collins WE, Wang Y, Chen ZW: Virus infection stages and distinct Th1 or Th17/Th22 T-cell responses in malaria/SHIV coinfection correlate with different outcomes of disease. J Infect Dis 2011, 204:1450-1462.

45. Bomsel M, Tudor D, Drillet AS, Alfsen A, Ganor Y, Roger MG, Mouz N, Amacker M, Chalifour A, Diomede L, et al: Immunization with HIV-1 gp41 subunit virosomes induces mucosal antibodies protecting nonhuman primates against vaginal SHIV challenges. Immunity 2011, 34:269-280.

46. Morner A, Jansson M, Bunnik EM, Scholler J, Vaughan R, Wang Y, Montefiori DC, Otting N, Bontrop R, Bergmeier LA, et al: Immunization with recombinant HLA classes I and II, HIV-1 gp140, and SIV p27 elicits protection against heterologous SHIV infection in rhesus macaques. J Virol 2011, 85:6442-6452.

47. Sundling C, O'Dell S, Douagi I, Forsell MN, Morner A, Lore K, Mascola JR, Wyatt RT, Karlsson Hedestam GB: Immunization with wild-type or CD4-binding -defective HIV-1 Env trimers reduces viremia equivalently following heterologous challenge with simian-human immunodeficiency virus. J Virol 2010, 84:9086-9095. 
48. Lagenaur LA, Sanders-Beer BE, Brichacek B, Pal R, Liu X, Liu Y, Yu R, Venzon D, Lee PP, Hamer DH: Prevention of vaginal SHIV transmission in macaques by a live recombinant Lactobacillus. Mucosal Immunol 2011, 4:648-657.

49. Subbarao S, Otten RA, Ramos A, Kim C, Jackson E, Monsour M, Adams DR, Bashirian S, Johnson J, Soriano V, et al: Chemoprophylaxis with tenofovir disoproxil fumarate provided partial protection against infection with simian human immunodeficiency virus in macaques given multiple virus challenges. J Infect Dis 2006, 194:904-911.

50. Pahar B, Wang X, Dufour J, Lackner AA, Veazey RS: Virus-specific T cell responses in macaques acutely infected with SHIV(sf162p3). Virology 2007 363:36-47.

51. Promadej-Lanier N, Hanson DL, Srinivasan P, Luo W, Adams DR, Guenthner PC, Butera S, Otten RA, Kersh EN: Resistance to Simian HIV infection is associated with high plasma interleukin-8, RANTES and eotaxin in a Macaque Model of Repeated Virus Challenges. JAIDS 2010, 53:574.

52. Singer R, Derby N, Rodriguez A, Kizima L, Kenney J, Aravantinou M, Chudolij A, Gettie A, Blanchard J, Lifson JD, et al: The nonnucleoside reverse transcriptase inhibitor MIV-150 in carrageenan gel prevents rectal transmission of simian/human immunodeficiency virus infection in macaques. J Virol 2011, 85:5504-5512.

53. Crostarosa F, Aravantinou M, Akpogheneta OJ, Jasny E, Shaw A, Kenney J, Piatak M, Lifson JD, Teitelbaum A, Hu L, et al: A macaque model to study vaginal HSV-2/immunodeficiency virus co-infection and the impact of HSV-2 on microbicide efficacy. PLoS One 2009, 4:e8060.

54. Kenney J, Aravantinou M, Singer R, et al: An antiretroviral/zinc combination gel provides 24 hours of complete protection against vaginal SHIV infection in macaques. PLoS One 2011, 6:e15835.

55. Viollet L, Monceaux V, Petit F, Fang RHT, Cumont M-C, Hurtrel B, Estaquier J: Death of CD4+ T cells from lymph nodes during primary SIVmac251 infection predicts the rate of AIDS progression. J Immunol 2006, 177:6685-6694.

56. Monceaux V, Viollet L, Petit F, Fang RHT, Cumont M-C, Zaunders J, Hurtrel B, Estaquier J: CD8+ T cell dynamics during primary simian immunodeficiency virus infection in macaques: relationship of effector cell differentiation with the extent of viral replication. J Immunol 2005, 174:6898-6908.

57. Monceaux V, Fang RHT, Cumont M, Hurtrel B, Estaquier J: Distinct cycling CD4 + -and CD8 + -T-cell profiles during the asymptomatic phase of simian immunodeficiency virus SIVmac251 infection in rhesus macaques. J Virol 2003, 77:10047-10059.

58. Fang RHT, Khatissian E, Monceaux V, Cumont MC, Beq S, Ameisen JC, Aubertin AM, Isral N, Estaquier J, Hurtrel B: Disease progression in macaques with low SIV replication levels: on the relevance of TREC counts. Aids 2005, 19:663.

59. Elbim C, Monceaux V, François S, Hurtrel B, Gougerot-Pocidalo M-A, Estaquier J: Increased neutrophil apoptosis in chronically SIV-infected macaques. Retrovirology 2009, 6:29.

60. Laforge M, Campillo-Gimenez L, Monceaux V, Cumont M-C, Hurtrel B, Corbeil J, Zaunders J, Elbim C, Estaquier J: HIV/SIV infection primes monocytes and dendritic cells for apoptosis. PLoS pathog 2011, 7:e1002087.

61. Champoux M, Higley JD, Suomi SJ: Behavioral and physiological characteristics of Indian and Chinese-Indian hybrid rhesus macaque infants. Dev Psychobiol 1997, 31:49-63.

62. Clarke MR, O'Neil JAS: Morphometric comparison of Chinese-origin and Indian-derived rhesus monkeys (Macaca mulatta). Am J Primatol 1999, 47:335-346.

63. Doxiadis GG, Otting N, de Groot NG, de Groot N, Rouweler AJ, Noort R, Verschoor EJ, Bontjer I, Bontrop RE: Evolutionary stability of MHC class II haplotypes in diverse rhesus macaque populations. Immunogenetics 2003, 55:540-551.

64. Otting N, de Vos-Rouweler AJ, Heijmans CM, de Groot NG, Doxiadis GG, Bontrop RE: MHC class I A region diversity and polymorphism in macaque species. Immunogenetics 2007, 59:367-375.

65. Penedo MC, Bontrop RE, Heijmans CM, Otting N, Noort R, Rouweler AJ, de Groot N, de Groot NG, Ward T, Doxiadis GG: Microsatellite typing of the rhesus macaque MHC region. Immunogenetics 2005, 57:198-209.

66. Viray J, Rolfs B, Smith DG: Comparison of the frequencies of major histocompatibility (MHC) class-II DQA1 and DQB1 alleles in Indian and Chinese rhesus macaques (Macaca mulatta). Comp Med 2001, 51:555-561.

67. Burdo TH, Marcondes MCG, Lanigan C, Penedo MCT, Fox HS: Susceptibility of Chinese rhesus monkeys to SIV infection. Aids 2005, 19:1704.
68. Hansen SG, Vieville C, Whizin N, Coyne-Johnson L, Siess DC, Drummond DD, Legasse AW, Axthelm MK, Oswald K, Trubey CM: Effector memory T cell responses are associated with protection of rhesus monkeys from mucosal simian immunodeficiency virus challenge. Nat Med 2009, 15:293-299.

69. Hansen SG, Ford JC, Lewis MS, Ventura AB, Hughes CM, Coyne-Johnson L, Whizin N, Oswald K, Shoemaker R, Swanson T: Profound early control of highly pathogenic SIV by an effector memory T-cell vaccine. Nature 2011, 473:523-527.

70. Watkins DI, Burton DR, Kallas EG, Moore JP, Koff WC: Nonhuman primate models and the failure of the Merck HIV-1 vaccine in humans. Nat Med 2008, 14:617-621.

71. Haigwood NL, Montefiori DC, Sutton WF, McClure J, Watson AJ, Voss G, Hirsch VM, Richardson BA, Letvin NL, Hu S-L: Passive immunotherapy in simian immunodeficiency virus-infected macaques accelerates the development of neutralizing antibodies. J Virol 2004, 78:5983-5995.

72. Hessell AJ, Poignard P, Hunter M, Hangartner L, Tehrani DM, Bleeker WK, Parren PW, Marx PA, Burton DR: Effective, low-titer antibody protection against low-dose repeated mucosal SHIV challenge in macaques. Nat Med 2009, 15:951-954.

73. Hessell AJ, Rakasz EG, Poignard P, Hangartner L, Landucci G, Forthal DN, Koff WC, Watkins DI, Burton DR: Broadly neutralizing human anti-HIV antibody $2 \mathrm{G} 12$ is effective in protection against mucosal SHIV challenge even at low serum neutralizing titers. PLoS pathog 2009, 5:e1000433.

74. Mattapallil JJ, Douek DC, Hill B, Nishimura Y, Martin M, Roederer M: Massive infection and loss of memory CD4+ T cells in multiple tissues during acute SIV infection. Nature 2005, 434:1093-1097.

75. Picker LJ, Hagen SI, Lum R, Reed-Inderbitzin EF, Daly LM, Sylwester AW, Walker JM, Siess DC, Piatak M, Wang C: Insufficient production and tissue delivery of CD4+ memory $T$ cells in rapidly progressive simian immunodeficiency virus infection. J Exp Med 2004, 200:1299-1314.

76. Campillo-Gimenez L, Cumont M-C, Fay M, Kared H, Monceaux V, Diop O, Müller-Trutwin M, Hurtrel B, Lévy Y, Zaunders J: AIDS Progression Is Associated with the Emergence of IL-17-Producing Cells Early After Simian Immunodeficiency Virus Infection. J Immunol 2010, 184:984-992.

77. Favre D, Lederer S, Kanwar B, Ma Z-M, Proll S, Kasakow Z, Mold J, Swainson L, Barbour JD, Baskin CR: Critical loss of the balance between Th17 and T regulatory cell populations in pathogenic SIV infection. PLoS pathog 2009, 5:e1000295

78. Klatt NR, Brenchley JM: Th17 cell dynamics in HIV infection. Curr Opin HIV AIDS 2010, 5:135.

79. Macal M, Sankaran S, Chun T, Reay E, Flamm J, Prindiville T, Dandekar S: Effective CD4\&plus; T-cell restoration in gut-associated lymphoid tissue of HIV-infected patients is associated with enhanced Th17 cells and polyfunctional HIV-specific T-cell responses. Mucosal immunol 2008, 1:475-488.

80. Campillo-Gimenez L, Laforge M, Fay M, Brussel A, Cumont M-C, Monceaux V, Diop O, Lévy Y, Hurtrel B, Zaunders J: Nonpathogenesis of simian immunodeficiency virus infection is associated with reduced inflammation and recruitment of plasmacytoid dendritic cells to lymph nodes, not to lack of an interferon type I response, during the acute phase. J Virol 2010, 84:1838-1846.

81. Ling B, Veazey R, Penedo C, Xu K, Lifson J, Marx P: Longitudinal follow up of SIVmac pathogenesis in rhesus macaques of Chinese origin: emergence of B cell lymphoma. J Med Primatol 2002, 31:154-163.

82. Degenhardt JD, De Candia P, Chabot A, Schwartz S, Henderson L, Ling B, Hunter M, Jiang Z, Palermo RE, Katze M: Copy number variation of CCL3-like genes affects rate of progression to simian-AIDS in Rhesus Macaques (Macaca mulatta). PLoS genetics 2009, 5:e1000346.

83. Ferguson B, Street SL, Wright H, Pearson C, Jia Y, Thompson SL, Allibone P, Dubay CJ, Spindel E, Norgren RB: Single nucleotide polymorphisms (SNPs) distinguish Indian-origin and Chinese-origin rhesus macaques (Macaca mulatta). BMC genomics 2007, 8:43.

84. Smith DG, McDonough J: Mitochondrial DNA variation in Chinese and Indian rhesus macaques (Macaca mulatta). Am J Primatol 2005, 65:1-25.

85. Loffredo JT, Maxwell J, Qi Y, Glidden CE, Borchardt GJ, Soma T, Bean AT, Beal DR, Wilson NA, Rehrauer WM, et al: Mamu-B*08-positive macaques control simian immunodeficiency virus replication. J Virol 2007, 81:8827-8832.

86. Mothe BR, Weinfurter J, Wang C, Rehrauer W, Wilson N, Allen TM, Allison DB, Watkins DI: Expression of the major histocompatibility complex class I molecule Mamu- $A^{*} 01$ is associated with control of simian immunodeficiency virus SIVmac239 replication. J Virol 2003, 77:2736-2740. 
87. Muhl T, Krawczak M, Ten Haaft P, Hunsmann G, Sauermann U: MHC class I alleles influence set-point viral load and survival time in simian immunodeficiency virus-infected rhesus monkeys. J Immunol 2002, 169:3438-3446.

88. Wambua D, Henderson R, Solomon C, Hunter M, Marx P, Sette A, Mothe BR: SIV-infected Chinese-origin rhesus macaques express specific MHC class I alleles in either elite controllers or normal progressors. J Med Primatol 2011, 40:244-247.

89. Southwood S, Solomon C, Hoof I, Rudersdorf R, Sidney J, Peters B, Wahl A, Hawkins $\mathrm{O}$, Hildebrand W, Mothé BR: Functional analysis of frequently expressed Chinese rhesus macaque MHC class I molecules Mamu-A1* 02601 and Mamu-B* 08301 reveals HLA-A2 and HLA-A3 supertypic specificities. Immunogenetics 2011, 63:275-290.

90. Southwood S, Solomon C, Hoof I, Rudersdorf R, Sidney J, Peters B, Wahl A, Hawkins $\mathrm{O}$, Hildebrand W, Mothé BR: Functional analysis of frequently expressed Chinese rhesus macaque MHC class I molecules Mamu-A1* 02601 and Mamu-B* 08301 reveals HLA-A2 and HLA-A3 supertypic specificities. Immunogenetics 2011, 63:275-290.

91. Garibal J, Laforge M, Silvestre R, Mouhamad S, Campillo-Gimenez L, Lévy Y, Estaquier J: IL-2 immunotherapy in chronically SIV-infected Rhesus Macaques. Virol J 2012, 9:1-15.

92. Nugeyre M-T, Monceaux V, Beq S, Cumont M-C, Fang RHT, Chêne L, Morre M, Barré-Sinoussi F, Hurtrel B, Israël N: IL-7 stimulates T cell renewal without increasing viral replication in simian immunodeficiency virus-infected macaques. J Immunol 2003, 171:4447-4453.

93. Beq S, Nugeyre M-T, Fang RHT, Gautier D, Legrand R, Schmitt N, Estaquier J, Barré-Sinoussi F, Hurtrel B, Cheynier R: IL-7 induces immunological improvement in SIV-infected rhesus macaques under antiviral therapy. J Immunol 2006, 176:914-922.

doi:10.1186/1742-4690-10-89

Cite this article as: Zhou et al:: SIV infection of rhesus macaques of Chinese origin: a suitable model for HIV infection in humans. Retrovirology 2013 10:89.

\section{Submit your next manuscript to BioMed Central and take full advantage of:}

- Convenient online submission

- Thorough peer review

- No space constraints or color figure charges

- Immediate publication on acceptance

- Inclusion in PubMed, CAS, Scopus and Google Scholar

- Research which is freely available for redistribution 